\title{
Narrativizing (and laughing) spatial identities together in Meänkieli-speaking minorities
}

\author{
Juha Ridanpää (Geography Research Unit, University of Oulu) \\ juha.ridanpaa@oulu.fi
}

\section{Highlights}

- Humor is a creative way to make sense of, produce and contest socio-spatial relations.

- For linguistic minorities humor functions as a means to contest hegemonic discourses.

- Laughter is a narrative method for approaching spatial identities.

- Meänkieli-speaking minorities utilize humor in their language revitalization work.

\begin{abstract}
This paper scrutinizes how the Meänkieli-speaking minority in The Torne Valley, northern Sweden, use humor in the process of narrativizing their shifting spatial identities, as well as in maintaining and contesting prevailing power relations. A great deal of the research focusing on the social and political nature of humor, and its geographical dimensions, has concerned the humor directed at ethnic and national minorities, with minority groups typically being approached as targets of laughter. However, less interest has been paid to how minorities use and experience humor in their everyday lives and environments. Humor is approached here as an integral part of how people make sense of culture and society in a creative manner and cope with and challenge subordinating power-relations and social inequality. In terms of methodology, laughing together operates as a (research) approach through which spatial identities of linguistic minorities can be renegotiated. The study is based on group discussions held with local culture workers and activists between September 2015 and February 2016 in Swedish Torne Valley. The paper produces new theoretical and empirical knowledge concerning how humor is used in a creative manner to make sense of, produce and contest socio-spatial relations.
\end{abstract}

\section{Keywords}

Humor; Minority languages; Meänkieli; Marginalization; Narrative; Regional identity

Ridanpää, J. (2017). Narrativizing (and laughing) spatial identities together in Meänkieli-speaking minorities. Geoforum, 83, 60-70. 


\section{Introduction}

Humor is an integral part of the creative manner in which people make sense of space, culture and society. Likewise, humor is a practical "tool" which helps people to cope with and challenge subordinating power-relations and social inequality. A great deal of the research focusing on the social and political nature of humor has concerned the humor directed at ethnic and national minorities, with minority groups typically being approached as targets of laughter (Gillota, 2013; Anderson, 2015; Weaver, 2015; Kuipers and van der Ent, 2016). However, less attention has been paid to how minorities use and experience humor in their everyday lives and environments. This notwithstanding, it is essential to emphasize that the socio-political nature of humor, its connection to marginalization and otherness, as well as the use of humor in practical everyday situations are not separate issues. The objective of this paper is to scrutinize how linguistic minorities, specifically the Meänkieli-speaking people of the Torne Valley, northern Sweden, use humor as a means to narrativize shared, but also controversial, identities.

As a universal communicative tool humor extends basically to every facet of human life. In this paper the focus is specifically on its role as an element of spatial narratives. Narratives are understood as representations and performances that are constrained by social norms, values and power relations, which at the same time are recreated through their own representations (see Wiles et al., 2005: 91). In this light, humor is understood here simultaneously as both content and as a form of narrative - which typically have not been studied together (see Sorsoli, 2007: 304). People use humor (both as a standpoint and as a rhetoric device) in the process of organizing, representing and reasoning their personal experiences, as well as in performing their identities. Different forms of regional, linguistic, and situational "knowledge" have a crucial role in the process of how the "funniness" of local narratives is comprehended and experienced (Ridanpää, 2012).

Meänkieli, a minority language spoken in the Torne Valley, northern Sweden, has a long history of marginalization and otherness. Within Swedish culture and society, while speaking and interacting in Meänkieli has long been something to be ashamed of, during the past three decades, along with the global "ethnic renaissance", Meänkieli language revitalization work has turned the local identity and heritage into something to be proud of. Humor in its various forms has played a fundamental role in this process. As a communicative device or performative tool, humor has been a key factor in establishing identity work in practice in cultural institutions such as local theatres, literature, music, radio broadcasts. Similarly, humor is also an inseparable part of local identity narratives. 
As a starting point this paper begins with a brief generalization of how spatiality in a wider sense becomes established and meaningful through the processes of story-telling (see Lorimer, 2003). The main questions here concern the ways in which power relations, particularly marginalizing practices, are made salient in regional narratives, but also how the socio-political aspects of the Torne Valley's history and heritage are embedded in local humor. Local humor is accessed here through group discussions conducted in the Torne Valley. Within these discussions humor is simultaneously approached as thematic content of the discussion and as a performative act, via the process of story-telling. The paper contributes to the geographical discussion over spatial identities and narratives by introducing how various dimensions of humor and laughter have a unique and multifaceted role in the process of identity making. Through dissecting how humor and narrativization are interconnected in the everyday lives of linguistic minorities, the paper offers a new approach to the construction of spatial identities.

\section{Spatial identities, narrations and humor}

Interest in the spatial nature of identities and belonging was first roused in the humanistic geography of the 1970s when, along with the concepts of "topophilia" (Tuan, 1974) and "sense of place" (Relph, 1976), attention was drawn to the subjective meanings attached to space and place. During the last two decades, the ambiguous nature of "identity" has been increasingly underscored (Brubaker and Cooper, 2000). In geographical research the term has often been approached from the perspective of how identity becomes constructed in the process of difference-making, in everyday practices, and in performances in which "self" is refined through making a categorical distinction with “other” (Massey, 2005: 192).

In geographical studies of identity, "belonging" has been one of the key concepts through which the connection between spatiality and identity has been approached. In fact, on some occasions belonging has even been used as a synonym for identity, although the relationship between these two terms, "belonging" and "identity", is much more complicated than this suggests (see Antonsich 2010). Identity can be perceived as a politics of belonging, which, according to Yuval-Davis (2006), needs to be studied on the levels of social locations, emotional attachments, and ethical and political values. In similar manner Antonsich (2010: 644) highlights how "belonging should be analyzed both as a personal, intimate, feeling of being 'at home' in a place (place-belongingness) and as a discursive resource that constructs, claims, justifies, or resists forms of socio-spatial inclusion/exclusion (politics of belonging)". "We feelings", as spatially embedded emotions, are not only about the feelings of belonging, but also about the feelings of being different (Richter, 2015), especially in the case of 
minority identities. Making a difference between "self" and "other" through personal expressions such as "I belong here" is always conditioned by various power relations (Antonsich, 2010: 652-653).

Geographers have studied belonging quite adequately within the context of citizenship (e.g. Secor, 2004; Nordberg, 2006; McConnell, 2013), while the explorations of local attachments and belonging are still relatively rare (Tomaney, 2015: 508). Emotional attachment to localities is often perceived as a manifestation of parochialism, with Tomaney defending parochialism, as a mode of dwelling, against cosmopolitanism, still arguing how parochialism does not "concern an inherent 'lack of global perspective' or an inevitable disregard for the other" (Tomaney, 2012: 668). Local nostalgia can also be productive. "The value of productive nostalgia" has been claimed as a concept through which local history practices and wider heritage movements can be explored (Wheeler, 2016).

Along with its instrumental and communicative roles, a primary function of language is to maintain group identity and shared feelings of belonging, and thus language has a key role in the process of how spatial identities are constructed (Edwards, 2010). For instance it has been argued that, on a general level, ethnic identities are constructed through language and everyday actions (Clayton, 2009), while identity narratives function as performances of spatial belonging. Through stories, people make sense of who they are, and what kinds of communities they belong to; stories may also be used to narrativize their positions in relation to others, that is, to emplot their spatial bearings and identities (Prokkola and Ridanpää, 2011). Local belonging, feeling "at home", can be expressed, in the form of narratives, both individually and collectively (Tomaney 2015: 508) and should always be understood contextually (Tomaney, 2012).

At this point it is essential to separate the concepts of "identity narrative" and "narrative identity". While the term "identity narrative" refers to the stories of peoples' self-conceptions (Yngvesson and Mahoney, 2000), the term "narrative identity" is commonly used to refer to the ways that individuals construct their personal stories in certain social circumstances, as well as to the ways in which communities construct their spatial identities through stories (Somers, 1994; Hearn, 2007), but also to how national and regional representations function as overlapping meta-narratives (Dittmer, 2007). Thus, if identity is understood as a politics of belonging, then belonging must not be perceived as status of being, but rather as a process of becoming, an act of performativity (Antonsich 2010: 652). The performative acts of speech, in the form of narratives, play a major role when relationships between identity and place are constructed (Gilmartin and Migge, 2015). Identities and identity discourses become formed as the outcomes of narrative self-reflection (cf. Vainikka, 2015), and in that way narrations work as linguistic strategies through which minority identities become established (Gilmartin and Migge, 2015). 
In narrative studies mention is often made of Margaret Somers (1994: 606), according to whom social identities are constituted through narratives and narrativity, or to put it another way, for whom narrativity is understood as a condition of social being and identity (Somers, 1994: 616). Following the key arguments of Somers, Prokkola (2014: 445) argues that "narrative plotting and practices can be understood as political actions in which particular social and cultural discourses are confirmed and others contested". In the case of place identities, narratives rely on miscellaneous elements, such as conceptions of nature, ethnicity, dialects, periphery/center relations, marginalization and stereotypic images of a people/community, and are intrinsically linked with how these elements are used in different forms of social practices, rituals and discourses (Paasi, 2003: 477). As language serves as an elementary facet of the development of nationalism (Anderson, 1983), the condition of being linguistically marginalized effectively means a reduced sense of belonging to the state (Valentine and Skelton, 2007). Narrativity is thus a social "performance" in which spatial processes and discourses of inclusion and exclusion become "storied" and also rationalized (see Newman and Paasi, 1998). Similarly, for emigrant minority groups, language is functions as a performance with which identity is sustained (Sullivan, 2012).

Understanding the contentious politics of memory as "performances" means acknowledging that competing visions of commemoration represent the means through which collective memories are negotiated (Bosco, 2004: 387). For ethnic and linguistic minorities, counter-narratives are a means through which hegemonic discourses can be contested, collective memories embodied and sociocultural self-identities established and performed. Although Valentine's (2000) study of the production of narratives of the "self" within the context of adult-child relationships is not perfectly compatible to or a perfect analogue to the narrative formation of ethnic and linguistic minority identities, it nevertheless illustrates well how some groups of people have more power over the content and forms of narrative identities than others. As an emotionally charged communicative device, humor is a unique part of story-telling. In the process of answering the simple question of "who are we", humor has several different interconnected functions. Firstly, when identity narratives are told, as they often are, in the form of humorous stories, or jokes, humor becomes a rhetorical tool of meaning making. For many people humor is an inseparable part of everyday communication, for which reason its unique role is often taken for granted. Although non-verbal humor has a long tradition, and finding certain issues humorous is likewise a matter of emotions and affects, language plays an elementary role in how we perceive certain topics or situations as humorous within certain circumstances. A number of studies on humor have explicitly pointed out how group identities are embedded as well as established 
through storied humor (e.g. Rothwell et al., 2011; Weckström, 2011). In fact, in Finnish words 'joke' and 'story' have a common etymological origin (Knuuttila, 1992).

In addition to narrativization, humor can also be used as an emotional technique, a performance through which the spatial identities of marginalization can be dealt with. Performance is understood here as a more or less conscious intent (see Schieffelin, 1998) in which humor is a means to renegotiate the subordinated identity of ethnic minorities. Similarly, humor or a specific sense of humor can be a characteristic of spatial identity for the groups themselves. Sense of humor differs between regions, or to put it another way, different kinds of senses of humor function as cultural practices through which regions and regionality become established. Similarly, it is commonly accepted that specific localities have their own unique forms of humor (Jokinen, 1996). Different places have their own unique senses of humor and thus humor becomes an identity marker for various scales of places and spaces.

But what makes certain issues, events, topics, and manners of performing them, humorous? It has been emphasized that humor becomes constituted as a series of moments in which absurdity is accepted (Atluri, 2011: 212). This does not mean that humor is based on absurdity. In fact, humor has been approached as a specific discursive mode in which absurdity is controlled through its own distinct rules (Mulkay, 1988). In addition it has been emphasized that humor, as a cultural institution, has a universal role in ensuring conformity and maintenance of social order (Billig, 2005: 201-202), in functioning as a route or method for dealing with strange, difficult and sensitive issues, and in alleviating a fear of the unknown and the uncontrollable (Vucetit, 2004).

This is a corresponding approach to Sigmund Freud's (1905/2002) classic conceptualization of humor in which he argues that humor functions as a safe outlet and an internal psychological means for (the pleasure of) breaking taboos and overcoming inhibitions. In similar vein, within social groups humor increases the sense of affinity and belonging, the "we-feeling" (Terrion and Ashforth, 2002; Vucetit, 2004); in terms of group dynamics, “joking is not something done by existing subjects, but how the comic constitutes subjectivity" (Atluri, 2011: 199). Oftentimes humor relies on preconceptions and popular stereotypes (e.g. Hamilakis, 2000; Ridanpää, 2007), although preconceptions and stereotypes are not funny as such. In fact, the existence of humor or perceiving something as humorous is ultimately a matter of situationality (Ridanpää, 2012). Certain forms of performances are commonly considered more admissible and natural within certain spatial, cultural and social situations.

Humor possesses a shared social purpose in fostering group cohesion and social bonding, as well as creation and preservation of group identities (Davies, 1990; Palmer, 1994), especially in daily interaction (Norrick and Chiaro, 2009). The concept of 'ethnic humor', used for instance by Shiftman and Katz 
(2005), is a good example of how the feeling of togetherness is seen as being intrinsically linked to the "institution" of laughter. In their study on the jokes of elderly Eastern Europeans at the expense of well-bred German Jews, Shiftman and Katz illustrate how humor functions as a specific means for immigrant minorities in the process of assimilating into new cultural environments. A similar study has been conducted by Hagar Salamon (2011), who has analyzed humorous stories circulating among Ethiopian Jewish immigrants and how their narratives "articulate the drama of dislocation and the traumatic encounter with life in Israel" (2011: 16). Laughter is an indication of sharing similar sociopolitical ideologies; in the context of gender and sexuality, a sense of sameness is often realized through shared laughter (Delph-Janiurek, 2001).

The connection between ethnicity and humor can be approached from two alternate perspectives. Firstly, ethnicity and ethnic groups have often been objects of laughter. Racial jokes have a long tradition and scholars across disciplinary boundaries have considered humor directed at minorities as by its nature insulting (cf. Hughes, 2003; Perks, 2010; Weaver, 2011). It is thus seen that ethnic jokes have a "victimizing" effect, notwithstanding that they may be embraced as part of a local tradition (Okada, 2007). A different viewpoint has emphasized how ethnic humor may also have a social function in countering hostility (Schutz, 1989). For instance Gibson (2013) has discussed within the context of the Australian working-class how place identity, class politics, and social processes such as ethnic marginalization become negotiated through humor in unexpected, ambiguous and creative manners.

Humor thus contains the potential to work as a device through which dominant discourses, i.e. "normal", hegemonic narratives, regional stereotypes and insulting preconceptions directed at ethnic minorities, can be contested (Ridanpää, 2007, Mascha, 2008; Ridanpää, 2010). In addition it has been argued that with globalization, and the digitalization of communication, the nature of stereotyping has changed from explicit towards a wider variety of stances (Boxman-Shabtai and Shifman, 2015). Social and political circumstances instantly have an impact on the nature of humor. For instance a study of 1000 randomly selected Persian jokes revealed that "the targets of Persian jokes are mostly ethnic and political issues which violate the social and political taboos and censorship to achieve their end" (Naghdipour, 2014: 105). In the case of national minorities, the accessory function of humor is crucial for instance with respect to how self-mocking works as a tool with which group self-identities are reflected (Davies, 1998, 2002). 


\section{Torne Valley and Meänkieli: Revitalizing an othered language}

Meänkieli, in English "our language", has played a fundamental role in the process of re-constructing regional identity in the Torne Valley. In fact, in some studies the history of Meänkieli language has been approached as being equivalent with the history of the Torne Valley's identity (see Lipott, 2015: 3-5). If we understand Meänkieli as folklore, its history goes back to the beginning of the $19^{\text {th }}$ century, when in the aftermath of the war of 1808-1809 the territory of Finland was separated from Sweden and annexed to Russia as the autonomous Grand Duchy of Finland. As a consequence of the new border the historically, linguistically, economically and culturally more or less homogeneous region of the Torne Valley was divided between two nations. As a result the Finnish-speaking population on the Swedish side of the Torne Valley region became a linguistic minority, whereas the people living in the territory annexed to Russia began to identify with the majority population and assumed the status of the national majority when Finland gained independence in 1917.

The condition of being a linguistic minority began to develop into an issue of social "othering" in the late $19^{\text {th }}$ century, when the Swedish national “försvenskningspolitik" entailed exercising powerful political pressure on marginal groups in order to integrate them linguistically and culturally into the modern nation-state. "Försvenskningnspolitik" with its aims of national security effected a practical categorical distinction with Russia, which during the era meant Finland, in all fields of human life, for the benefit of national security. Finnish-speaking people were perceived as an ethnically inferior population, an internal "other", compared to the Swedish-speaking majority (Huss, 1999; Elenius, 2002) - "a fact" that was ostensibly "proved" by the racial studies of Swedish anthropologists (Heith, 2012). Through institutional control, especially related to the school system, the marginalization of the Swedish Torne Valley became a concrete and mundane part of people's lives. For instance speaking Finnish in schools was forbidden during the first half of the $20^{\text {th }}$ century (see Júliusdóttir, 2007: 41).

The cognizance of being socially marginalized rose remarkably in the 1970s, and along with the global "ethnic renaissance" of the late $20^{\text {th }}$ century a rise in social self-esteem and aspirations to preserve one's own culture and language has become stronger in the Torne Valley (see Lindgren, 2000; Winsa, 2007). As a counter-reaction to state integration and language repression, new forms of regional activity evolved (Prokkola, 2008: 660). At the same time, people became more conscious of the fact that the language they spoke in everyday situations, "our language", was something to be proud of and worth revitalizing. Although the distinct status of Meänkieli has often been questioned (Piasecki, 2014: 13), in 2000 the language was granted official status as a minority language in five municipalities in northern Sweden: Gällivare, Kiruna, Haparanda, Pajala and Övertorneå. Revitalization of Meänkieli 
language and culture, an act of making the voice of a historically marginalized minority heard, can also be seen as part of a wider discussion concerning the rise of multiculturalism and polynationalism in Swedish society, as is also evidenced in the agonistic responses from political groups against this development (see Heith, 2013: 86).

As the origin of the language lies in Finnish, Meänkieli is often seen, especially in Finland, as a dialect of Finnish rather than a separate language of its own. Characteristic of Meänkieli is its extensive and variable use of h-sounds, loaning of several Swedish words and certain forms of regression compared to how Finnish in Finland has developed during the past 200 years (see Vaattovaara, 2009). Currently approximately 50000 people live in the Torne Valley, of whom, according to Ethnologue: Languages of the World, approximately 30000 are Meänkieli speakers. However, the exact number of Meänkieli speakers is highly difficult to estimate, since people living in the Torne Valley are often uncertain whether the language they use can actually be defined as Meänkieli or not. It is also important to emphasize that the notion of a coherent, shared cultural heritage in the Torne Valley has been criticized. Anne Heith (2009: 73), for instance, has pointed out that locality and ethnic roots have been represented in a contradictory manner in local literature.

The organization for revitalizing Tornedalian culture and language, Svenska Tornedalingars Riksförbund (STR-T), was established in 1981. In addition, there are several individuals who have worked in different roles towards revitalizing Meänkieli and the local identity. For example, the politician Ragnar Lassinantti (1915-1985) did substantial work on behalf of all Finnish-speaking minorities in Sweden, while Bengt Pohjanen, who published the first novel in which Meänkieli was used, Kasaland (1984), and a grammar of Meänkieli, Meänkielen Kramatiikki (1996), has provided the basis for Meänkieli as a literary language (see Prokkola \& Ridanpää 2011). Reminiscent of the "land of the Welsh" (see Jones and Fowler, 2007), Pohjanen has also regionalized his artistic work by establishing a narrative of a harmonious Meänkieli-speaking region: "Meänmaa" (“Our Land”). Although Meänmaa has not been recognized on any governmental level, it is nevertheless possible to be granted a (symbolic) passport of Meänmaa, whose sole practical purpose is that locals can get a discount from local shops.

What has been unique in recent developments of the linguistic revitalization of Meänkieli is the special role of humor. In the national context the social status of Meänkieli-speaking minorities was a relatively unfamiliar topic before local novelist Mikael Niemi published his breakthrough novel Popularmusik, fran Vittula (Popular Music from Vittula) in 2000, the same year Meänkieli attained its official minority language status. The book has been translated into 30 languages and has provided a career boost to other local novelists. Written with an eye for folk tradition and regional identity, Populärmusike 
Från Vittula is a humorous story focused on a Finnish/Meänkieli-speaking young boy growing up in Pajala. The story follows local life in the 1960s and '70s, describing, in ironic fashion, what being marginalized and othered means on the level of the everyday (see Ridanpää 2014a). In the wake of Niemi's success several Meänkieli-speaking artists have become famous by utilizing humor in their productions. For example, the humorous music of R $a j R a j$ Band and the Meänkieli-singing reggae band The Meänland have gained a degree of notoriety. Similarly the local radio station in Pajala, Meän Raatio, organizes annual joke-telling contests in Meänkieli.

\section{Methodologies of hearing stories and laughing in groups}

In the case of minority studies, group discussion has been understood to occupy a special role as a methodic route by which oppressed minorities may make their voices heard (Booth and Booth, 1996). For a researcher, participation in group discussions, on the other hand, is a specific method through which the multiplicity of shared as well as contested narratives of spatial belonging and identity can be discovered (Price, 2010). In this paper the group discussions are analyzed through narrative inquiry. Narrative inquiry is commonly used to refer to a subset of qualitative research designs in which stories are used to examine and describe human action (Polkinghorne, 1995). "Little stories" make sense of reality, meaning that 'hearing stories' can be used as a sensitive methodological tool (Prokkola, 2014).

Although it plays a significant role in communication and daily interaction, in the social studies in which group discussions have been utilized humor has relatively rarely been taken into particular consideration. In those rare studies where participant observation of focus groups has been used, it has been noticed that humor functions as a mechanism through which group identities become established, "materialized" if you like (see Terrion and Ashforth, 2002; Kuipers, 2010). For instance, in group discussion studies conducted earlier in Sweden it was noticed how, compared to other discourses, narrations of Finnishness were invariably played down with laughter (Weckström, 2011). Similarly, in focus group discussions humor has been used as an alternate research method through which intimately political conversations about everyday practices can be accessed (Browne, 2016). Participation in group discussions is a particularly useful method with respect to interpreting how humor is utilized in the expression of the multitude of narratives, for example, in the process of putting both shared and controversial meanings of spatial identities into words, at the same time enabling researcher to see possible conflicts and confrontations through the experiences of humor.

The empirical material of this study consists of 8 tape-recorded, approximately 1-1.5 hour long, group discussions, conducted with 32 persons of whom 17 were women and 15 men. Of these groups, 
3 were comprised of men and women, 3 only of women, and 2 only of men. The discussions were held in Haparanda, Övertorneå, Svanstein, Korpilombolo, Aapua and Pajala, between September 2015 and February 2016. As preliminary group cohesion is a highly important factor within the context of minority identities, the people participating in the discussions were 1) already familiar with each other, signifying a certain level of trust, and 2) had a shared social bond related to the research topic. The participants were selected to represent people who are (inter-)actively working in several types of local associations and organizations operating around the Torne Valley, and are involved, some directly, some more indirectly, with the revitalization of Meänkieli: members of village associations and cultural associations, teachers from different levels of schools, local radio reporters and musicians. The purpose for recruiting the focus groups from these various types of organizations was to dissect how different communities process humor in different, possibly controversial manners. Although many of the participants play key roles in the process of Meänkieli language revitalization, the transcripts are analyzed here anonymously. The names mentioned during the discussions have been changed.

All discussions were held in Meänkieli although there were natural alterations in language use depending on the backgrounds of different discussants. Some discussants conceived their own language to be Finnish, instead of Meänkieli, while for some discussants the use of Swedish was, or would have been, more comfortable during the discussions. In fact, changing languages from Meänkieli/Finnish to Swedish and back again even during a single sentence, is highly typical for Meänkieli speakers. In fact, it can be considered a unique characteristic of the language. Before the discussions started, the thematic background of my study as well as my personal research interests in the connections between Meänkieli and humor were briefly but openly presented to the participants. In this manner humor, and laughter, attained a twofold role during the discussions: Laughter was simultaneously understood both as a performative act of narrativization and also as a topic of narrativization. In the group discussions the participants occasionally specifically talk about the characteristics of local humor, while simultaneously attention is paid to how laughter becomes used as a communicative device. The discussions were informal and spontaneous, and my purpose as a researcher was to take as passive a role as possible. For each discussion a separate thematic framework was prepared, which contained questions relating to the specific activities of the interviewed group (music, radio broadcasting, religion, and so) and also questions that were directed to all interviewed groups:

- How do you see the work on Meänkieli language revitalization?

- How does the issue of minority language come up or need to be acknowledged in your work? 
- In what way do people in the Torne Valley differ from people living in Finland or southern Sweden?

- Is everyday life somehow different compared to Finland or southern Sweden?

- What do you think of local 'humorists'?

These questions, which had been compiled to support the theoretical framework of the present study, were formulated in case the spontaneous discussion ceased for some reason. It is essential to emphasize that the occasions when the interviewer needed to broach these topics were rare. The issues above were typically brought up by the discussants themselves and often discussed in the form of story-telling. The participants were not specifically directed to tell stories. Some of the narrations were based on the personal experiences of the discussion participants, or incidents that their friends or relatives had experienced, while others were described as "true events" that had happened to "someone", "somewhere", at "some time". This latter narrations were sometimes repeated in several discussions in different forms, as local legends. Hearing stories and laughing in groups turned out to be a useful method through which it was possible to access alternative versions of identity narratives.

\section{Laughing in Meänkieli - laughing at Meänkieli}

\subsection{Characteristics of Tornedalian bumor}

As emphasized in this paper, the connection of humor, spatiality and identity is an interesting one and one that clearly straddles local narratives. Senses of humor differ regionally, or to put it another way, different senses of humor function as narrative tools through which the very essence of regionality is established. As mentioned earlier, specific localities have their unique forms of humor (Jokinen, 1996), and similarly it has been studied how there are regional variations in how sarcasm is used (Dress et al., 2008). A specific, unique form of humor is not just one communicative device among others, but it also defines the principal question of "who I am". In fact, during the discussions the comment "humor is one thing that separates us from others" was often repeated, although this "other" referred to quite different subjects in different discussions.

The characterization of shared identities often starts with a cursory description of "what kind of people we are". One feature that was considered specifically characteristic of Tornedalian personality was modesty, often flavored with self-conscious humor. In GROUP 8 it was retold how, partly owing to the long history of being othered, a person grown up in the Torne Valley does not say after dinner 
that "the food was delicious", but rather that "it was not that bad". Accordingly, hosts do not ask from their guests whether the food had been good, but rather whether it was eatable. Another man in that group told a short story about his brother who had a habit of saying "sure, I can have a shit after this", when he wanted to accentuate that the food had been exceptionally delicious. Although for many people from outside the region these sorts of utterances may signify a serious lack of modesty, for locals these examples particularly exemplify how modest a people they are. In order to understand this connection between being (ostensibly) rude and modest at the same time, one needs to be able to comprehend the form of local sarcasm in which an ironic manner of saying the opposite of what is intended works as a narrative tool for establishing a conception of "us" as people who have no need to praise themselves.

When discussing whether there were any specific modes of humor characteristic of the Torne Valley and Meänkieli, it was constantly mentioned how coarse Meänkieli is and how for this reason routine interaction between "us" and "them" commonly results in confusing situations, which later take on a narrative form as a story to be repeated and remembered - with laughter. Using curse words in one's language is considered a natural part of everyday life, a basic characteristic of Meänkieli. "Paska", "shit", is therefore a natural word and its meaning cannot be captured with a more polished synonym, while an attempt to do so becomes a subject for a humorous story. In the group discussions several narratives in which "the collapse of decency codes" were related resulted in laughter. The topic was brought up in the following discussion:

\begin{abstract}
GROUP 6, Man 2: We have some words that Finns think like "ouch, that was awful how you said it". I always remember when we had our first child and we were visiting in Finland, and I said to my wife that "take a new nappy - the son had a shit." There was somebody sitting next to me who said: "Almighty Jesus! Do you say that he 'bad a shit??" [laughter] "Well, of course. He had a shit." "But you don't say about a baby that he had a shit." [laughter] But I was thinking, what had I said wrong? He had a shit! [very load laughter] "Say it more nicely, like poo or something", but I didn't find it weird.
\end{abstract}

There is a general consensus that different forms of humor are connected with different types of people. Irony for instance is stereotypically seen as connected with intelligence, sophistication and wit, and therefore is best practiced by highly educated, intellectual males (Barbe, 1995: 4-5). Similarly, studies on humor which utilize participant observation of group discussions as a method have proven how the patterns of humor that are used in group interaction are closely linked with status-related activities (Robinson and Smith-Lovin, 2001). In a similar vein, Friedman and Kuipers (2013) argue that 
the one's taste in humor, especially the limit at which point good taste is considered to have been crossed, is ultimately a matter of social class, albeit they do not assume that "taste differences automatically translate into hierarchical boundaries" (2013: 180). The previous example does not actually exemplify the coarse nature of Tornedalian humor, but rather it demonstrates, on a meta-level, how differences between regional language codes result in situations that locals find humorous. It would be easy here to withdraw to an interpretation of how the above example in fact simply validates the appropriateness of the stereotype of the primitive, non-civilized, vulgar Tornedalian man (cf. Eriksson, 2010). However, it is important to emphasize that these humorous stories were both laughed at and told by women too. The previous narration with a different variation was told in a group where there were only women participating, for instance. Women also told stories about what had happened to their friends and relatives - stories, that some may consider rude and indecent. For Meänkieli speakers finding right words is often difficult, which then leads into humorous situations and humorous stories:

GROUP 6, Woman 2: My husband's sister, she speaks Meänkieli, of course, and she is daring. She speaks like everywhere. (...) She had gone to Finland to wash a car, a place like where you drive the car inside. She went and thought that she will get the bottom of the car also washed, the chassis. She went inside, into that room and said she wanted to wash the car. Ok - think nothing of if - she thought (...) and said, "and then I want to have my bottom cleaned too." [loud laughter for a long time]

The story was followed by the roars of laughter, after which one man in group adds: "If it's important, just spread the legs and let the brush do the work". The narrator finishes the story:

GROUP 6, Woman 2: But that thing they use for washing the chassis was out of order. Maria said, how she saw how that boy, or man, looked at her (...), and said: "Dear lady, it cannot be done, because the rod is broken." [loud laughter]

What was particularly interesting to find was that almost every time that the coarse nature of Meänkieli was brought up, a certain tone of self-conscious pride was noticeable. Being coarse is a part of their identity, something normal that 'they' just don't understand, and the coarser all this sounds to you or makes you feel, the stronger the identity is present. On the other hand, it was emphasized in several discussions by both women and men that coarse language, as an identity marker, is not something that everyone accepts without reservation.Coarse language as an identity marker has its 
unique background in Mikael Niemi’s breakthrough novel Popularmusik, frän Vittula (Popular Music from Vittula) (2000/2003). The word "Vittula" is Finnish/Meänkieli, referring to a place where there are plentiful female genitals, “cunts”. In Laurie Thomson's translation of the book, Vittula is translated as "Cuntsmire", the name originating, according to the book, from the relatively high birth rate in the region. During the discussions it was several times mentioned how the use of such a place name sounds horrible to the Finns ("them"), but for local people ("us") it is just normal. There were also other stories about relatively coarse place names. In GROUP 4 a woman told a story about"Pillujoki", "Cunt River", the name originating at a time when women participated in log driving on that place, which situated along Torne River, which was highly exceptional. Similarly it was related how the village of Valkeakoski is locally called "Paskala", "Shit Village", the name originating in the days when the village used to function as a spot where horses stopped eating fodder and emptied their bowels. It was told how back in the old days the locals did not appreciate these names, but rather considered them as an insult, while for others the stories behind the names were and still are something to laugh about. These humorous place names, and especially the stories through which they become renewed, operate as reminiscences of local history and everyday life. The geography of region, language and local heritage become entwined and are kept alive through humorous place names as part of the local narratives. In fact the same woman related how locals nowadays have started to like and appreciate these nicknames, simply because of the history and tradition behind them. In interdisciplinary studies on humor it has been emphasized how humor is in many ways a gendered mode of communication, how men and women have different senses of humor, how their purposes in using humor are different, and so on (e.g. Walker and Dresner, 1988; Lundell, 1993). In sociolinguistic studies, for instance, it has been found that telling funny stories is a preference specifically in female humor. The conception of women lacking the 'skill' of humor is mostly based on stereotypes and androcentric ideas about what is funny (Coates, 2014: 148). Although the gender variations of Tornedalian humor were not a specific research question in this study, it came as a slight surprise that the same jokes were told and laughed at both by women and men, regardless of how the groups were divided by gender. In addition, perceiving rude humor as unappealing was an opinion shared by both women and men. Based on these discussions it is essential not to make too hasty generalizations, as deductions about the gendered differences in the taste of Tornedalian humor would be highly difficult based on these discussions.

Although during the group discussions there were no noticeable differences between how males and females told stories or reacted to them, the shared opinion, of both male and female participants, turned out to be that in the Torne Valley in many ways humor is a mode of communication exemplified by men. And this, in itself, resulted in an excursion into several narratives in which the 
stereotypes of Tornedalian man became simultaneously contested and confirmed - always with laughter. Foremost, local humor is considered to originate from events in which men are doing typically manly things, for example hunting elk in the forest. A male participant describes how

GROUP 3, Man 2: Humor, it has lived here for a long time, in one form or another, (...) it may be that it's in these camps, where men have been in their forest cabins. But no mothers, they have been home with children. They run out of bumor like that. [laughter]

In similar fashion to how local tradition stays alive in humorous place names, traditions related to local everyday habits and routines are kept alive through humor. In the region there is an old moral code that emphasizes waking up early as a virtue. Over the years, or centuries, this has turned into a subject for light-hearted competitions, or rather a topic for narrations of competition in which humor plays a central role. Although cooking meat soup is far from the best example of (stereo)typical local masculine activities, it illustrates nonetheless how competing with other men is a daily practice that is always accompanied by laughter. As one man relates, GROUP 4, Man 1: "We still have competitions, when we go to Mauno's early, at three o'clock in the morning, and Mauno always talks about how he has cooked meat soup already". This quip results in shared loud laughter after which a female discussant continues, Woman 2: "I'm in the habit of mentioning that I have cooked meat soup, but that's not until eight o'clock." "Who is the best man at this and that" is a common framework for humorous stories, but the aspect of masculinity becomes present especially in those narratives in which a lack of masculinity is turned into a subject of joking:

GROUP 4, Man 1: Camilla's husband, Matti, he used to bake once in a while. And when he would start baking in the morning, his wife watched through the window so that nobody saw what he was doing. [loud laughter for a long time]

Although the negative stereotype of the Tornedalian masculine man is often repeated in Swedish popular media (Eriksson, 2010), on the other hand these narrations illustrate their role as part of a behavioral code that is dominant in the region. Behaving in a feminine way, even using an umbrella, can provoke laughter. On the other hand, these narrations, narrations like men competing in baking, also illustrate that the general stereotypes of masculinity are not necessarily the same as what performing masculinity in everyday life is in practice. Another context in which manliness also becomes present is that of narratives that are relatively cruel but nevertheless conceived by the locals themselves as 
somehow humorous. One man told a true story about a boy who had broken his skis when jumping a hill:

GROUP 4, Man 1: Once there was an incident when we were at school, we used to make jumps on the bills and one fellow had new skis. And we made this jump and he jumped it for the first time, crashed down and the skis snapped in half right down the middle. Well, we left the place, and he went to his mom, to say what had happened. His father was chopping wood there in the yard, and he had pretty poor hearing. I went bebind the corner when the boy opened the door and his mom came against him. She saw what had happened and she yelled to her husband: "Börge, Börge, kill this son! He is in chewing tobacco and blood and bis skis are broken!” [loud laughter for a long time]

Woman 1: That was quite a rough reception.

Man 1: And I said to him that he was lucky his father had such poor hearing. [loud laughter]

The general opinion during the discussions was that similar to how coarse words are used in Meänkieli, humor in the Torne Valley is by its nature relatively rough. The previous narration may not sound remotely funny for many people, but when told and heard by the locals, together with their friends, sharing laughter is a normal response. The story was told with 'serious face' but still accompanied with by much laughter in the group. As one interviewed man from GROUP 1 summarized this "regionality of humor": "Here people are capable of laughing at the sort of things that those living in the south would feel shocked by."

\subsection{Humor embedded: Is Meänkieli a 'funny' language?}

One important issue concerning the interconnections between humor, identity, minority languages and also otherness relates to the question of whether the language can be comical in itself. For example, speaking English with a Scottish accent has in some contexts been used as a rhetorical vehicle to provoke laughter, by using the dialect as if it were humorous in itself. In similar fashion, in several sources it has been either implied or directly argued that Meänkieli is somehow "a funny language" (see e.g. Hurme, 1996; Kantokorpi, 1997). During the discussions some of the discussants underlined how humor is, indeed, embedded in their language. There were several explanations for this. In one version the funniness of Meänkieli was connected with the obscenity of the language, which, as discussed above, is often considered one of the key characteristics of Meänkieli. Another explanation for was that the lack of grammar consistency makes everyday situations in the language sound humorous. A woman 
in GROUP 5mentioned how "when you're inflecting words, some gibberish comes out once in a while". Many discussants underlined that they think, or have heard others say that Meänkieli is a 'heartwarming language' that makes you smile when you hear it. As one woman put it:

GROUP 2, Woman 2: When I was working in Luleä, there was a Finn in the same workplace, and she said that, "ooh, you are so lovely to listen to. You talk. like my old grandma."

While for many Meänkieli was first and foremost a 'heart-warming language', there were also those who considered flattering statements more or less insulting. One woman, who is actively participating in language revitalization work, told a story from her past:

GROUP 8, Woman 2: I have been in the tourism business before, working as a travel guide in Lulea. I had many groups from Finland. I remember one group, for example, who said that "ou, this has been so lovely this tour". And I thought that, ou, I have done good work. "It is your language. I have just sat down and listened to it". They didn't know where we had been. They just listened my language all the time. And recalled their childhood memories.

A third explanation for why Meänkieli was considered funny as such relates to the issue that Meänkieli is largely a context-bound language. Meänkieli is used in everyday situations when dealing with mundane issues, while there are several topics which cannot be communicated fluently, in a natural manner, in Meänkieli. On these sorts of occasions the conversation is cut practically in the middle of the sentence and continued in Swedish, and after the topic changes again, the language returns to Meänkieli. Issues of an official nature, such as banking, tax legislation, administration, governance, etc., are simply impossible to discuss in Meänkieli. Similarly holding religious events like church services in Meänkieli feels, on the one hand cozy and warm, but on the other, somehow peculiar:

GROUP 7, Woman 1: Some serious issues feel difficult to speak about in Meänkieli. It is a colloquial language.

Woman 2: Exactly, it is a colloquial language. Everyday language, if you may. (...)

Woman 1: (...) but like in church services, it is quite new, and we have not gotten used to it, but it feels like home. It is so pleasant to listen to. But when we were in Pello, it was the first time, [laughter], I watched this man and he could not help laughing when the Bible was read in Meänkieli. [laughter] That situation was so weird. 
Finding the use of Meänkieli humorous in this situation follows the classic incongruity theory of humor, in which it is argued that laughter is the result of a situation in which people are confronted with concepts or situations which are surprisingly in discordance with their expectations (e.g. McGhee, 1979). Although the situation may be unexpected and weird, for people using the language it still feels heart-warming and jolly. Another context in which Meänkieli, in contrast to Finnish, becomes humorous concerns the alternate meanings of words. One man told a story from his student days, about how his words were misunderstood by the Finns:

GROUP 8, Man 5: And no matter how small a house you had, here we call them "mansions". I noticed that too when I lived a few years in Sweden and met Finns there in the university. We talked and finally they asked that where on earth do you live, as all of you have mansions there? [loud laughter]

The double-meanings of words can create humorous narratives, told as true stories from real life. In the previous example the different nuances of the meaning of one word turn into a humorous situation, while some words in Meänkieli have a completely different meaning compared to Finnish. There were several "true stories" about how the confusing words have caused hilarious situations. For example the verb "eksyä", which in Finnish means "to get lost”, in Meänkieli means “to faint”, while amusingly fainting in Meänkieli means dying in Finnish. A person who had long ago moved from Finland to Sweden explained:

GROUP 6, Woman 2: I had just started dating Hans and we were on a visit somewhere and one man there explained how, huh, how his wife (...), she's awful, you can't go anywhere with her, she faints. Leave her alone? Not a chance, she faints. When she goes home, she faints. Behind the house, she faints. And I just wondered, what a strange person she was. [laughter] Before I figured it out that she gets lost. While in Finland "to die", when bere we say that someone dies, it means fainting in Meänkieli. And then there was once the time when someone (...) asked "what happened to bim?" "Nothing special, he just died." [laughter]

Although the previous example was originally told in Meänkieli, the narration becomes hilarious only after it is comprehended as a Finnish narration. It thus turns into a narrative act in which the difference between Meänkieli speakers and Finnish speakers, “us” and "them”, become established through humor, also exemplifying the performative nature of humor (cf. Palmer, 1994). There are several reasons as to why Meänkieli seems humorous, as a funny language as such, but from the 
viewpoint of language revitalization the point can be insulting. One participant who is actively involved with language revitalization work told about his personal experiences:

GROUP 3, Man 1: One thing I've figured out is that many folks in Finland think that we are humorists simply because of this language, because the language feels so amusing. (...) We do not see that we are humorists by the language, (...) but I've figured it out in Finland that this sort of a reaction may come. (...) I was once in Kolari, it was a long time ago. I was giving some kind of lecture there about some issue here. It was the Adult Education Center and there were lots of people, about a bundred in that hall. And I watched how they were giggling all the time and I was talking about serious issues! [laughter] Is my pants zipper open? [laughter] What is wrong with me? And later I heard what it was all about.

What is emphasized strongly in all the previous examples is that it is "those Finns" who consider Meänkieli a funny language; thus at this point humor, or laughter to be precise, functions as a tool of othering between states, not between different dialects spoken in different regions. Thus the question about the funniness of the language becomes a personal question. For some the question about whether Meänkieli is funny as such touches on the issue of "laughing in Meänkieli", jesting in it; for others the question is about "laughing at Meänkieli", making fun of it. But examining these two viewpoints as opposing is not that simple. In fact, there was a clear sound of bitterness detectable when the previous story was related, but the story was still accompanied by shared laughter. In addition, although it is understandable that people involved in language revitalization highlight the mockery aspect here, school teachers for example underlined how "having fun" is an elementary part of learning the language.

\subsection{Proud of being othered}

Although the main purpose of the group discussions was to talk about the role of the minority language, local habits and their relation to humor, it was also interesting and instructive to see how laughter became a performative act during the narrations. Laughter is a universal feature of communication, so making overly extensive conclusions about the laughter in the discussions and local identity should be avoided. However, there were clear moments when laughter happened spontaneously as well as moments when the room became silent because of the serious nature of the topics under discussion. Meänkieli language preservation was generally considered to be an extremely serious topic, which became evident in several cases when the hilarious laughter simply stopped when 
the topic of discussion changed. However, on some occasions certain hilarious aspects were found in this topic as well, no matter how serious an issue it may be. Some participants considered Meänkieli more or less an 'artificial invention', which caused jolly laughter among the other participants. When one female discussant introduced herself with a serious voice, "I have always said that I speak Finnish, it was before this Meänkieli was invented" (GROUP 2, Woman 3), the other participants in the discussion started to laugh. Similarly the topic about what is correct and what is incorrect Finnish, or Meänkieli, was often accompanied by laughter.

People who are actively working with language revitalization are very aware of the social status of their language and culture, so it was highly interesting to find that some of the discussants were capable of laughing at their minority status. As mentioned earlier, self-mocking functions as a tool with which group self-identities are reflected, especially among minority groups (Davies, 1990, 1998). However, in the case of Meänkieli self-mocking does not appear to represent a safety-valve which would help people live with their othered identities, but rather the humor works as a means though which minority status becomes a source of pride. In fact, in several cases the Tornedalian jokes followed the general rules of the superiority theory of humor. According to classic superiority theory, laughter is an outcome of the feeling of being superior to the object of joke, through which it follows that laughter can often be "ignorant" or "hostile" (Bergson, 1911; Feinberg, 1978). In the examined narratives the sense of superiority over those who do not speak Meänkieli is clearly present, although the origin of this feeling is, slightly paradoxically, often grounded on the consciousness of being inferior:

GROUP 8, Man 1: I was working at the County Administrative Board during the late '70s and my assignment was to educate municipalities in construction work, how to take account of different risk factors when building population centers and so on. And I had my superintendent with me, who was a Swedish-speaking woman, and she listened to my presentation and when we came home she said that: "My God, Lars! You must fix your Swedish. Everyone hears where you come from. You have such a dialect that you must get rid of it - everyone bears where you come from." That pissed me off and I said, "exactly, you're right there, and when you speak, nobody knows where you come from." She didn't say a word after that." [laughter]

As speakers of a minority language, Tornedalian people often face situations in which not only their language but also their dialect of Swedish becomes challenged. Meänkieli-speaking people speak Swedish with a Finnish accent, and during the late '70s that dialect was something that many people were ashamed of. To quote Mikael Niemi (2003: 49): "We spoke with a Finnish accent without being Finnish, and we spoke with a Swedish accent without being Swedish. We were nothing." Mastering 
proper Swedish-speaking skills was considered a virtue, one rarely challenged during those days. Along with language revitalization work attitudes have changed and currently mastery of both Meänkieli (or Finnish) and Swedish is considered useful and valuable. At the same time, people who do not understand Meänkieli at all, and speak only Swedish, are locally referred to as "ummikko" (in English, literally an "enclosed person"), a term which has turned into an object of laughter. There were several humorous stories about these people and their difficulties in dealing with everyday situations in which communicating in Swedish is simply impossible, despite that all the participants in situation are able to speak it fluently. For example, hunting elk is an activity carried out in Meänkieli, so to participate in hunting with poor skills in Meänkieli has resulted in several hilarious narratives:

GROUP 4, Woman 2: They had been chasing elk. for the whole day and the group leader spoke to the walkietalkie...,

Woman1: Yes, in the walkie-talkie.

Woman 2: ... that now we go home, assuming that everyone understood what he said, in Meänkieli. Then one young wife calls him that where was her husband, since he had not come home yet. He was ummikko. [laughter] He had stayed sitting on his stand, as he did not understand what was said. [laughter] But he lived, he did not die there. [laughter] You can manage, you survive. [laughter] But much you miss much if you don't understand the language.

Lacking certain language skills makes an individual (partly) an outsider, a common characteristic of the link between language and identity. These sorts of events and narratives validate the identity at local level, but also highlight distance to other regions, in this case southern Sweden. Alongside the issues of culture and language, the far distance to the big cities in southern Sweden has been one of the cornerstones of the Tornedalian (marginalized) identity. The narratives about how "they" in the south have a peculiar image of "us" is a subject of wonder and amazement, but also of laughter. In a group discussion held in Korpilombolo, a small village of 800 people in the northernmost part of Sweden, the southern preconceptions about the Torne Valley were described as unbelievable:

GROUP 4, Woman 1: I have heard many times, when they have come from the south here, they have mentioned and even called by phone that "Korpilombolo, does that kind of place really exist?" [laughter] They have just believed that it is something that you say when you scare your kids. Like, "if you don't behave, we will send you to Korpilombolo". 
Children in south can be scared with the mythic northern village of Korpilombolo only because adults know that such a place does not actually exist. But when adults hear that such a place actually exists, even they have to call there to make sure. The matter of being marginal and marginalized within Swedish society is reflected in the narratives about "them" living far away "there" in the south, in big cities, having a distorted image of "us". This partly also exemplifies how the remoteness of a place can be a factor that strengthens the sense of belonging (see Bocco, 2016). As a socio-politically charged narration, this anecdote may feel highly serious, but nonetheless it is still told with laughter, with bemusement, not ignoring the seriousness of the issue, but rather acknowledging its irony. With the success of Mikael Niemi's humorous book it became natural that being marginal is nothing to be ashamed of. In fact, living "nowhere" in the middle of the wilderness has ironically been turned into a tourist attraction by local tourism promoters in Pajala (see Ridanpää, 2011). Being different, being marginal, need not be something to be ashamed of, but rather to be proud of, and laugh at.

\section{Conclusions}

Narrations, stories replicated over generations, are performances through which the meanings, or to be precise, the whole essence of spatial belonging becomes established. Humor can be interpreted as one nuance of local narrations, but if we approach narrations as performances in which identities become constructed, identities being narrative, then humor and laughter play much a more crucial role. Humor is a cultural phenomenon that, on the one hand, is an inseparable element of everyday lives, but on the other, is not suitable for all situations or conversations. There are topics that are far too serious to be laughed at, without being condemned, and others that just feel unnatural to be narrated with laughter.

From a sociocultural perspective humorous narratives function as performances in which the categorical separation between "us" and "them" is put into action. Normally, this happens when minorities become the targets of laughter, but laughing can also work as a lens for perceiving the sensitive parts of regional history, like the heritage of being a national minority, from a totally new perspective. Thereby humor may have an emancipatory impact. When we pay specific attention to the humorous aspects of the stories, or comprehend narrations as humor, new nuances for the interpretation of the social construction and change of spatial identities are found. This is a perspective which has not been adequately acknowledged by human geographers yet.

As this study demonstrates, spatial identities become laughed at and laughed about relatively naturally. Laughter is an inseparable part of togetherness, while for the benefit of establishing and 
strengthening regional identity humor works as an irreplaceable tool. Instead of "regional humor" it might better be called "humorous regionality". The very idea of regional togetherness and identity is established, kept alive and developed through humor and laughter. Laughing in groups, together, is also a highly helpful methodic perspective since it unveils the very essence of sharing emotions, "wefeelings". On the other hand, laughing in groups is a highly complicated method to use, since as earlier studies have shown, it is common that sensitive issues can be silenced with laughter (Weckström, 2011), both during the research events and in case of daily conversations. On the other hand, for the studies of narrative identities these sorts of incidences may turn out to be notable research findings.

As argued in the beginning, language plays a key role in how spatial identities become constructed. In case of Meänkieli, "our language”, the connection of language and identity, and its position within Swedish society, is self-evident, but what became evident during group discussions was that arguments like "Meänkieli is humorous as such" were not accepted as identity markers without reserve. Instead, some discussants considered such an argument an insult, directed at "us", by "outsiders". However, in both cases the arguments over the connections of Meänkieli and humor turn into narratives in where regional belonging and we-feelings become highlighted.

In humor studies the aspect of gender is for good reason often taken seriously (Walker and Dresner, 1988; Lundell, 1993; Coates, 2014), but the way the genderedness of Tornedalian humor emerged in the narratives was complicated. Tornedalian humor was considered manly, not only by the men themselves, but by women too, who not only shared this conception, but also told the same humorous stories and jokes with similar stresses as men. What was characteristic of Tornedalian humor was that the topics that were laughed at were sometimes not funny at all, at least not to this researcher. The distinction between "serious" and "humorous" was often blurred, which in truth tells much about the character of minority identities in general (see more about the seriousness of humor in the context of geography, Ridanpää 2014b).

The connection of situatedness and identity is often exemplified by the (feeling of) citizenship (Secor, 2004; Nordberg, 2006; McConnell, 2013). However, the case of Tornedalian humor illustrates that although citizenship works as a basis for establishing we-feelings and stories about "us", it may simultaneously function as a narrative constituent that is used in humorous stories for maintaining and strengthening regional belonging. In fact, Tornedalen can be used as an example of "borderland identity", a multivoiced group of partly contradictory narratives from two sides of the river on the Swedish-Finnish border (Prokkola, 2009). The question of citizenship and multiple belonging is often seen as a complex and problematic issue (e.g. Colombo, Domaneschi and Marchetti, 2011) and Tornedalen also has a long history of "being ashamed". Nevertheless, as this study has proved, humor 
can be used as a narrative tool for altering collective self-perceptions, turning the essence of we-feeling from shame to pride. The Torne Valley is a marginalized region and Meänkieli a marginalized language, which from the sociocultural and political points of view are extremely serious issues, but through humor these discourses of otherness have been turned into a resource, something to be proud of. Marginality does not disappear along with humor, but it rather contests the conventional meaning of the word.

What was surprising during the discussions was that the construction of the minority identity was quite often contrasted against discourses of Finnishness, though probably more often compared to the discourses of hegemonic Swedish culture and society. It is thus important to notice that although minority identities become established through the categorical distinction between 'us' and 'them', there still can be diverging narrations as to who this 'they' actually are. In fact, in addition, the question of who "we" refers to is in the case of Meänkieli-speaking people far from a simple one. Identity narratives are often conflicting and inconsistent. As Prokkola (2014: 443) formulates it, "it is important to recognize that the stories people tell and retell rarely form a coherent and logical narrative plot or identity-speech; rather, individual people may perform and 'live with' rather contradictory and antithetical narratives". However, establishing any identity without narratives, at any spatial level, would be simply impossible. Humor is a narrative tool which makes narrators and their audiences feel more comfortable, stories more delectable and the feeling of shared identity stronger.

\section{References}

Anderson, B., 1983. Imagined Communities: Reflections of the Origins and Spread of Nationalism. Verso, London.

Anderson, L., 2015. Racist Humor. Philosophy Compass 10 (8): 501-509.

Antonsich, M., 2010. Searching for Belonging - An Analytical Framework. Geography Compass 4 (6), 644-659.

Atluri, T., 2011. Lighten up?! Humour, Race, and Da off colour joke of Ali G. Media, Culture and Society 31 (2), 197-214.

Barbe, K., 1995. Irony in Context. John Benjamins Publishing Company, Amsterdam.

Bergson, H., 1911. Laughter: An essay on the meaning of the comic. MacMillan, New York.

Billig, M., 2005. Laughter and Ridicule. Towards a Social Critique of Humour. Sage, London.

Bocco, G., 2016. Remoteness and remote places. A geographic perspective. Geoforum 77: 178-181. 
Booth, T., Booth, W., 1996. Sounds of Silence: Narrative research with inarticulate subjects, Disability \& Society $11(1), 55-70$.

Bosco, F. J., 2004. Human rights politics and scaled performances of memory: conflicts among the Madres de Plaza de Mayo in Argentina. Social \& Cultural Geography 5 (3), 381-402.

Boxman-Shabtai, L., Shifman, L., 2015. When ethnic humor goes digital. New Media \& Society 17 (4), 520-539.

Browne, A. L., 2015. Can people talk together about their practices? Focus groups, humour and the sensitive dynamics of everyday life. Area 48 (2), 198-205.

Brubaker, R., Cooper, F. 2000. Beyond “identity”. Theory and Society 29, 1-47.

Clayton, J., 2009. Thinking spatially: towards an everyday understanding of inter-ethnic relations. Social and Cultural Geography 10 (4), 481-498.

Coates, J., 2014. Gender and Humor in Everyday Conversation. In: Ed. Chiaro, D., Baccolini, R. (Eds.) Gender and Humor: Interdisciplinary and International Perspectives. Routledge, New York, pp. 147-164.

Colombo, E., Domaneschi, L., Marchetti, C., 2011. Citizenship and multiple belonging. Representations of inclusion, identification and participation among children of immigrants in Italy. Journal of Modern Italian Studies 16 (3): 334-347.

Davies, C., 1990. Ethnic Humor around the World: A Comparative Analysis. Indiana University Press, Bloomington, Ind.

Davies, C., 1998. Jokes and their Relation to Society. Druckerei Hildebrand, Berlin.

Davies, C., 2002. The Mirth of Nations. Transaction Publishers, New Jersey.

Delph-Janiurek, T., 2001. (Un)consensual conversations: betweenness, `material access', laughter and reflexivity in research. Area 33 (4), 414-421.

Dittmer, J., 2007. Changing American Metanarratives of Russia in NATO Expansion Debates, 19932002. National Identities 9 (1), 49-66.

Dress, M. L., Kreuz, R. J., Link, K. E. \& Caucci, G. M., 2008. Regional Variation in the Use of Sarcasm. Journal of Language and Social Psychology 27 (1), 71-85.

Edwards, J., 2010. Minority Languages and Group Identity. John Benjamins B. V., Amsterdam.

Elenius, L., 2002. A Place in the Memory of Nation. Minority Policy towards the Finnish Speakers in Sweden and Norway. Acta Borealia 19, 103-123.

Eriksson M., 2010. (Re)producing a periphery: Popular representations of the Swedish North. Department of Social and Economic Geography, Umeå.

Feinberg, L., 1978. The Secret of Humor. Rodopi, Amsterdam. 
Freud, S., 1905/2002. The Joke and Its Relation to the Unconscious. Penguin Classics, New York. Friedman, S., Kuipers, G., 2013. The Divisive Power of Humour: Comedy, Taste and Symbolic Boundaries. Cultural Sociology 7 (2), 179-195.

Gibson, C., 2013. Welcome to Bogan-ville: reframing class and place through humour. Journal of Australian Studies 37 (1), 62-75.

Gillota, D., 2013. Ethnic humor in multiethnic America. Rutgers University Press, New Brunswick.

Gilmartin, M., Migge, B., 2015. Home stories: immigrant narratives of place and identity in contemporary Ireland. Journal of Cultural Geography 32 (1), 83-101.

Hamilakis, Y. 2000. No laughing matter: Antiquity in Greek political cartoons. Public Archaeology 1 (1), 27-72.

Hearn, M., 2007. Cultivating an Australian Sentiment: John Christian Watson's Narrative of White Nationalism. National Identities 9 (4), 351-368.

Heith, A., 2009. Contemporary Tornedalian Fictions by Ester Cullblom and Annika Korpi. Nordic Journal of Feminist and Gender Research 17 (2), 72-88.

Heith, A., 2012. Ethnicity, Cultural Identity and Bordering : A Tornedalian Negro. Folklore 52, 85-108.

Heith, A., 2013. Challenging and Negotiating National Borders : Sámi and Tornedalian Alternative Literary History. In: Viljoen, H. (Ed.) Crossing Borders, Dissolving Boundaries. Rodopi, Amsterdam, pp. 75-91.

Hughes, M. K., 2003. Through the Looking Glass: Racial Jokes, Social Context, and the Reasonable Person in Hostile Work Environment Analysis. Southern California Law Review 76 (6), 1437 1482.

Hurme, J., 1996. Hyvä tappaja. Image 1996 (4), 44-47.

Huss, L. M., 1999. Reversing language shift in the far North: linguistic revitalization in Northern Scandinavia and Finland. Acta Universitatis Upsaliensis, Uppsala.

Jokinen, M., 1996. Sysmäläinen nauru. Sysmäläinen kansanhuumori humorististen kertomusten valossa. In: Kinnunen, E., Koski, K., Penttilä, R., Pietilä, M. (Eds.) Vitsistä videoon. Uusia kirjoituksia kansanperinteestä. Suomalaisen Kirjallisuuden Seura, Helsinki, pp. 159-182.

Jones, R., Fowler, C., 2007. Where Is Wales? Narrating the Territories and Borders of the Welsh Linguistic Nation. Regional Studies 41 (1), 89-101.

Júlíusdóttir, M., 2007. Culture, cultural economy and gender in processes of place reinvention. In Nyseth, T., Granås, B. (Eds.) Place Reinvention in the North - Dynamics and Governance Perspectives. Nordregio, Stockholm, pp. 39-53. 
Kantokorpi, M., 1997. Kymppi juksauksessa. Rosa Liksomia lukiessa. In: Kantokorpi, M. (Ed.)

Muodotonta menoa: Kirjoituksia nykykirjallisuudesta. WSOY, Porvoo, pp. 7-29.

Knuuttila, S., 1992. Kansanhuumorin mieli: Kaskut maailman kuvan aineksena. Suomalaisen kirjallisuuden seura, Helsinki.

Kuipers, G. 2010. Humor Styles and Symbolic Boundaries. Journal of Literary Theory 3: 2, 219-239.

Kuipers, G., van der Ent, B., 2016. The seriousness of ethnic jokes: Ethnic humor and social change in the Netherlands, 1995-2012. HUMOR: International Journal of Humor Research 29 (4), 605633.

Lindgren, A., 2000. Language Emancipation: The Finnish Case. In: Phillipson, R. (Ed.) Rights to Language: Equity, Power and Education. Laurence Erlbaum Associates, Mahwah, pp. 40-45.

Lipott, S., 2015. The Tornedalian Minority in Sweden. From Assimilation to Recognition: A 'Forgotten' Ethnic and Linguistic Minority, 1870-2000. Immigrants \& Minorities 33 (1): 1-22.

Lorimer, H., 2003. Telling small stories: Spaces of knowledge and the practice of geography. Transactions of the Institute of British Geographers 28, 197-217.

Lundell, T., 1993. An experiential exploration of why men and women laugh. HUMOR: International Journal of Humor Research 6 (3), 299-317.

Mascha, E., 2008. Political satire and hegemony: A case of "passive revolution" during Mussolini's ascendance to power 1919-1925. HUMOR: International Journal of Humor Research 21 (1), 69-98.

Massey, D., 2005. For Space. Sage, London.

McConnell, F., 2013. Citizens and refugees: constructing and negotiating Tibetan identities in exile. Annals of the Association of American Geographers 103 (4): 967-983.

McGhee, P. E., 1979. Humor: Its origin and development. W. H. Freeman, San Francisco.

Mulkay, M., 1988. On Humor. Basil Blackwell, New York.

Naghdipour, B., 2014. Jokes in Iran. Folklore: Electronic Journal of Folklore 59, 105-120.

Newman D., Paasi, A., 1998. Fences and neighbours in the postmodern world: boundary narratives in political geography. Progress in Human Geography 22 (2), 186-207.

Niemi, M., 2003. Popular Music from Vittula. Translated from the Swedish by Laurie Thompson. Seven Stories Press, New York.

Nordberg, C., 2006. Claiming citizenship: marginalised voices on identity and belonging. Citizenship Studies 10 (5): 523-539.

Norrick, N.R., Chiaro, D., (Eds.) 2009. Humor in Interaction. John Benjamins B.V., Amsterdam. 
Okada, K., 2007. An analysis of Hawaii's tradition of local ethnic humor. University of Hawaii Law Review 30 (1), 219-241.

Paasi, A. 2003. Region and place: regional identity in question. Progress in Human Geography 27 (4), 475-485.

Palmer, J., 1994. Taking Humour Seriously. Routledge, London.

Perks, L.G., 2010. Polysemic Scaffolding: Explicating Discursive Clashes in Chapelle's Show. Communication, Culture and Critique 3 (2), 270-289.

Piacecki, K., 2014. The Birth of New Ethnoses: Examples from Northern Europe. Our Europe. Ethnography - Ethnology - Anthropology of Culture 3, 7-20.

Polkinghorne, D. E., 1995. Narrative configuration in qualitative analysis. International Journal of Qualitative Studies in Education 8 (1), 5-23.

Price, P., 2010. Cultural geography and the stories we tell ourselves. Cultural Geographies 17 (2), 203210.

Prokkola, E., 2008. Border Narratives at Work: Theatrical Smuggling and the Politics of Commemoration. Geopolitics 13 (4), 657-675.

Prokkola, E., 2009. Unfixing borderland identity: Border performances and narratives in the construction of self. Journal of Borderlands Studies 24 (3): 21-38.

Prokkola, E., 2014. Using Narrativity as a Methodological Tool. ACME: An International E-Journal for Critical Geographies 13 (3), 442-449.

Prokkola, E., Ridanpää, J., 2011. Following the plot of Bengt Pohjanen’s Meänmaa: Narrativization as a process of creating regional identity. Social \& Cultural Geography 12 (7), 775-791.

Relph, E., 1976. Place and Placelessness. Pion Limited, London.

Richter, M., 2015. Can you feel the difference? Emotions as an analytical lens. Geographica Helvetica 70 (2): 141-148.

Ridanpää, J., 2007. Laughing at northernness: postcolonialism and metafictive irony in the imaginative geography. Social \& Cultural Geography 8 (6), 907-928.

Ridanpää, J., 2010. A Masculinist Northern Wilderness and the Emancipatory Potential of Literary Irony. Gender, Place \& Culture 17 (3), 319-335.

Ridanpää, J., 2011. Pajala as a literary place: in the readings and footsteps of Mikael Niemi. Journal of Tourism and Cultural Change 9 (2), 104-118.

Ridanpää, J., 2012. The Media and the Irony of Politically Serious Situations: Consequences of the Muhammed Cartoons in Finland. Media, Culture \& Society 34 (2), 131-145. 
Ridanpää, J., 2014a. Politics of literary humour and contested narrative identity (of a region with no identity). Cultural Geographies 21 (4), 711-726.

Ridanpää, J., 2014b. Seriously Serious Political Spaces of Humor. ACME: An International E-Journal for Critical Geographies 13 (3), 450-456.

Robinson, D. T., Smith-Lovin, L., 2001. Getting a Laugh: Gender, Status, and Humor in Task Discussions. Social Forces 80 (1), 123-158.

Rothwell, E., et al. 2011. Joking Culture: The Role of Repeated Humorous Interactions on Group Processes During Challenge Course Experiences. Journal of Experimental Education 33 (4), 338-353.

Salamon, H., 2011. The Floor Falling Away: Dislocated Space and Body in the Humour of Ethiopian Immigrants in Israel. Folklore 122 (1), 16-34.

Schieffelin, E. L., 1998. Problematizing Performance. In: Hughes-Freeland, F. (Ed.) Ritual, Performance, Media. Routledge, London, pp. 194-207.

Schutz, C., 1989. The Sociability of Ethnic Jokes. HUMOR: International Journal of Humor Research 2 (2), 165-177.

Secor, A., 2004. "There is an Istanbul that belongs to me": citizenship, space, and identity in the city. Annals of the Association of American Geographers 94 (2): 352-368.

Shiftman, L., Katz, E., 2005. “Just Call Me Adonai”: A Case Study of Ethnic Humor and Immigrant Assimilation. American Sociological Review 70 (5), 843-859.

Somers, M. R., 1994. The narrative constitution of identity: A relational and network approach. Theory and Society 23, 605-649.

Sorsoli, L., 2007. Like pieces in a puzzle: Working with layered methods of reading personal narratives. In: Bamberg, M., De Fina, A., Schiffirin, D. (Eds.): Selves and Identities in Narrative and Discourse. John Benjamins Publishing Co., Amsterdam, pp. 303-324.

Sullivan, T., 2012. 'I want to be all I can Irish': the role of performance and performativity in the construction of ethnicity. Social \& Cultural Geography 13 (5), 429-443.

Terrion, J. L., Ashforth, B. E., 2002. From 'I' to 'We': The Role of Putdown Humor and Identity in the Development of a Temporary Group. Human Relations 55 (1), 55-88.

Tomaney, J., 2013. Parochialism-a defence. Progress in Human Geography 37 (5): 658-672.

Tomaney, J., 2015. Region and place II: Belonging. Progress in Human Geography 39 (4), 507-516.

Tuan, Y.-F., 1974. Topophilia: A Study of Environmental Perception, Attitudes and Values. Columbia University Press, New York. 
Vaattovaara, J., 2009. Meän tapa puhua: Tornionlaakso pellolaisnuorten subjektiivisena paikkana ja murrealueena. Suomalaisen Kirjallisuuden Seura: Helsinki.

Vainikka, J., 2015. Reflexive identity narratives and regional legacies. Tijdschrift voor economische en sociale geografie 106 (5): 521-535.

Valentine, G., 2000. Exploring children and young people's narratives of identity. Geoforum 31 (2), 257-267.

Valentine, G., Skelton, T., 2007. The right to be heard: Citizenship and language. Political Geography $26(2), 121-140$.

Vucetit, S., 2004. Identity is a Joking Matter: Intergroup Humor in Bosnia. Spaces of Identity 4 (1), 734.

Walker, N., Dresner, Z., (Eds.) 1988. Redressing the Balance: American Women's Literary Humor from Colonial Times to the 1980s. University of Mississippi Press, Jackson.

Weaver, S., 2011. The Rhetoric of Racist Humour: US, UK and Global Race Joking. Ashgate, Farnham.

Weaver, S., 2015. The rhetoric of disparagement humor: An analysis of anti-semitic joking online. HUMOR: International Journal of Humor Research 28 (2): 327-347.

Weckström, L., 2011. Representations of Finnishness in Sweden. Finnish Literature Society: Helsinki.

Wheeler, R., 2016. Local history as productive nostalgia? Change, continuity and sense of place in rural England. Social \& Cultural Geography DOI: 10.1080/14649365.2016.1189591.

Wiles, J. L., Rosenberg, M. W., Kearns, R. A., 2005. Narrative analysis as a strategy for understanding interview talk in geographic research. Area 37 (1), 89-99.

Winsa, B., 2007. Social capital of indigenous and autochthonous ethnicities. In: Dana, L., Anderson, R. B. (Eds.) International Handbook of Research of International Entrepreneurship. Edward Elgar Publishing, Chelterham, pp 257-286.

Yngvesson, B., \& Mahoney, M. A., 2000. As One Should, Ought and Wants to Be' Belonging and Authenticity in Identity Narratives. Theory, Culture \& Society 17(6): 77-110.

Yuval-Davis, N., 2006. Belonging and the politics of belonging. Patterns of Prejudice 40 (3): 197-214. 